\title{
Aplikasi Go Sigap sebagai wujud peningkatan pelayanan publik yang lebih mudah bagi masyarakat dengan berbasis teknologi informasi
}

\section{Go Sigap application as a request for improving public services easier for communities based on information technology}

\author{
Engkos Sarkosi \\ Program Studi Magister Kajian Ilmu Kepolisian, Sekolah Pascasarjana, Universitas Airlangga \\ Surabaya, 60286, Jawa Timur, Indonesia \\ E-mail: engkos.sarkosi-2015@pasca.unair.ac.id
}

\begin{abstract}
Abstrak
Penyelenggaraan kebijakan dengan berbasis teknologi informasi (TI) melalui aplikasi yang bisa diakses langsung melalui ponsel adalah sesuatu yang tidak bisa dihindari serta harus dilaksanakan oleh setiap instansi pemerintahan. Kepolisian Resor Gresik melakukan inovasi pelayanan publik dalam rangka mewujudkan program Promoter dari Kapolri dan melaksanakan reformasi birokrasi dengan memanfaatkan kecanggihan teknologi informasi melalui program yang bernama "Go Sigap". Tujuan dari penelitian ini adalah untuk menyiapkan aplikasi go sigap sebagai wujud peningkatan pelayanan publik yang lebih mudah bagi masyarakat dengan berbasis teknologi infomasi. Peneliti menggunakan metode desktiptif kualitatif dengan melakukan wawancara, observasi maupun dokumentasi secara mendalam agar mampu mendapat data yang valid. Hasilnya, pembentukan go sigap sebagai inovasi kebijakan berbasis teknologi dan informasi telah sesuai dengan tahapan pada pembentukan kebijakan berbasis inovasi teknologi informasi yakni melalui tahapan (1) pengetahuan (knowledge); (2) bujukan (persuasion); (3) keputusan (decision); (4) pelaksanaan (implementation); dan (5) konfirmasi (confirmation). Ada beberapa kendala dalam mempersiapkan go sigap mulai dari anggaran, penyiapan teknologi bahkan SDM.
\end{abstract}

Kata kunci: polisi; pelayanan publik; teknologi

\begin{abstract}
Implementation of policies based on information technology (IT) through applications that can be accessed directly via mobile phones is something that cannot be avoided and must be carried out by every government agency because the number of active cellular telephones in Indonesia is now 320 million with more integrated cellular internet networks from 100 million users. Gresik Resort Police is one of the innovators for IT-based public services in the East Java Regional Police. In order to create a safe and conducive situation of Security and Public Order (Kamtibmas) with excellent technology-based services, the Gresik Regional Police has made many public service innovations in order to realize the Promoter program of the National Police and carry out bureaucratic reforms that are more reliably utilizing information technology sophistication by carrying out information technology sophistication by carrying out public services through a program called "Go Spry". The purpose of this study is to prepare a spry go application as a form of improving public services that are easier for the community based on information technology. Researchers use qualitative descriptive methods because of complex problems and require an understanding of meaning in depth, so it needs to be done in-depth interviews, observations and documentation in order to be able to get valid data. As a result, the formation of alacrity as an innovation in technology and information-based policies is in accordance with the stages in the formation of policies based on information technology innovation through stages (1) knowledge, (2) persuasion, (3) decision (Decision), (4) Implementation, and (5) confirmation (Confirmation). There are some obstacles in preparing to go swiftly starting from the budget, preparing technology and even human resources.
\end{abstract}

Keywords: police; public policy; technology

\section{Pendahuluan}

Kepolisian Resor Gresik merupakan salah satu inovator untuk pelayanan publik berbasis TI di lingkup Kepolisian Daerah Jawa Timur. Dalam rangka menciptakan situasi Keamanan dan Ketertiban Masyarakat (Kamtibmas) yang aman dan kondusif dengan pelayanan prima berbasis teknologi, Polres Gresik telah melakukan banyak inovasi pelayanan publik dalam rangka mewujudkan program Promoter dari Kapolri dan melaksanakan reformasi birokrasi layanan yang lebih terpercaya memanfaatkan kecanggihan teknologi informasi dengan mengusung pelayanan publik melalui 
program yang bernama "Go Sigap". Dasar pembentukan dari program Go Sigap ini berdasarkan Rencana Kerja Polres Gresik Tahun Anggaran 2016 serta didasakan pada program inovasi Kapolres Gresik AKBP Adex Yudiswan terkait Pelayanan Publik berbasis IT. Go Sigap secara resmi telah dirilis oleh Menteri Pemberdayaan Aparatur Negara dan Reformasi Birokrasi dan Kepala Kepolisian Republik Indonesia di Sidoarjo pada hari Kamis 1 September 2016.

Penyelenggaraan kebijakan dengan berbasis teknologi informasi (TI) melalui aplikasi yang bisa diakses langsung melalui ponsel adalah sesuatu yang tidak bisa dihindari serta harus dilaksanakan oleh setiap instansi pemerintahan dikarenakan jumlah telepon seluler aktif di Indonesia saat ini sebesar 320 juta dengan telepon seluler yang terintegrasi jaringan internet lebih dari 100 juta pengguna. Sedangkan dari data statistik yang dirilis Asosiasi Penyelenggara Jaringan Internet menyebutkan bahwa 65\% pengguna internet ada di Pulau Jawa.

Ada beberapa fitur yang dapat digunakan oleh masyarakat tanpa harus melakukan registrasi terlebih dahulu, di antaranya informasi terkini, berita nasional, informasi lokasi kantor polisi, lokasi kantor pemerintahan, tempat wisata, nomor-nomor penting, lokasi pelayanan SIM keliling dan berbagai informasi lain yang bermanfaat bagi penggunanya. Sedangkan untuk fitur utama seperti panic button (tombol bantuan darurat), pengaduan, laporan polisi, layanan surat kehilangan, pengajuan pembuatan SIM baru / perpanjangan dan pengajuan SKCK baru/perpanjangan, pengguna harus melakukan registrasi dengan data yang valid terlebih dahulu. Data yang dimaksud antara lain Kartu Identitas Penduduk (KTP), SIM, Pasport, nomor telepon dan foto. Data yang dimasukkan oleh masyarakat akan diverifikasi kebenarannya dengan data yang ada pada dukcapil maupun data registrasi perdana kartu SIM pada telepon seluler.

Dampak kebijakan yang ditimbulkan dengan adanya pelayanan berbasis aplikasi melalui program Go Sigap memiliki dampak kebijakan yang ditimbulkan. Antara lain dampak organisasional serta dampak pada masyarakat. Dampak organisasional adalah dari suatu kebijakan dapat dirasakan oleh suatu organisasi atau kelompok, baik secara langsung maupun tidak langsung. Sedangkan dampak kebijakan pada masyarakat menunjukkan sejauh mana kebijakan tersebut mempengaruhi kapasitas masyarakat dalam melayani anggotanya, karena masyarakat merupakan suatu unit yang melayani para anggotanya (Wibawa 1994).

Peresmian Go Sigap merupakan bentuk difusi inovasi. Difusi inovasi terdiri dari dua padanan kata yaitu difusi dan inovasi. Rogers (1983) mendefinisikan difusi sebagai proses dimana suatu inovasi dikomunikasikan melalui saluran tertentu dalam jangka waktu tertentu di antara para anggota suatu sistem sosial (the process by which an innovation is communicated through certain channels overtime among the members of a social system). Di samping itu, difusi juga dapat dianggap sebagai suatu jenis perubahan sosial yaitu suatu proses perubahan yang terjadi dalam struktur dan fungsi sistem sosial. Sedangkan inovasi adalah suatu gagasan, praktek, atau benda yang dianggap/dirasa baru oleh individu atau kelompok masyarakat. Ungkapan dianggap/dirasa baru terhadap suatu ide, praktek atau benda oleh sebagian orang, belum tentu juga pada sebagian yang lain. Kesemuanya tergantung apa yang dirasakan oleh individu atau kelompok terhadap ide, praktek atau benda tersebut.

Dari kedua padanan kata tersebut, maka difusi inovasi adalah suatu proses penyebar serapan ide-ide atau hal-hal yang baru dalam upaya untuk merubah suatu masyarakat yang terjadi secara terus menerus dari suatu tempat ke tempat yang lain, dari suatu kurun waktu ke kurun waktu yang berikut, dari suatu bidang tertentu ke bidang yang lainnya kepada sekelompok anggota dari sistem sosial. Tujuan utama dari difusi inovasi adalah diadopsinya suatu inovasi (ilmu pengetahuan, tekhnologi, bidang pengembangan masyarakat) oleh anggota sistem sosial tertentu. Menurut Ibrahim (1988), proses difusi inovasi terdiri dari 5 tahap, yaitu: pengetahuan, bujukan, keputusan, implementasi, dan konfirmasi.

Sementara itu, secara etimologis, pelayanan berasal dari kata layan yang berarti membantu menyiapkan atau mengurus keperluan seseorang. Pelayanan merupakan aktivitas yang diberikan untuk membantu, menyiapkan dan mengurus baik itu berupa barang atau jasa dari satu pihak kepada pihak 
lain (Hardiyansyah 2011). Menurut Ivancevich, Lorenzi, Skinner dan Crosby, pelayanan adalah "produk-produk yang tidak kasat mata (tidak dapat diraba) yang melibatkan usaha - usaha manusia dan menggunakan peralatan" (Ratminto 2013; Nina 2013). Sedangkan pelayanan publik menurut Undang-undang Nomor 25 Tahun 2009 tentang Pelayanan Publik pada ayat 1 menyatakan bahwa: Pelayanan publik adalah kegiatan atau rangkaian kegiatan dalam rangka pemenuhan kebutuhan pelayanan sesuai dengan peraturan perundangundangan bagi setiap warga negara dan penduduk atas barang, jasa, dan/atau pelayanan administratif yang disediakan oleh penyelenggara pelayanan public (Sahya 2014).

Dalam menilai kualitas layanan menurut Fandy \& Anastasia (2003) mendasarkan pada lima dimensi pokok yang berkaitan dengan kualitas layanan untuk membentuk fokus pengguna. Kelima dimensi kualitas layanan tersebut sebagai berikut :Penampilan (tangible), yaitu penampilan fisik pelayanan (fasilitas fisik, peralatan), personel dan media komunikasi akan memberikan warna dalam pelayanan. Tingkat kelengkapan peralatan/teknologi yang digunakan dapat berpengaruh pada pandangan pelanggan atau kesiapan perusahaan dalam memberikan pelayanan. Kehandalan (reliability), yaitu kemampuan dalam memenuhi janji, tepat waktu, konsisten dan kecepatan pelayanan merupakan hal yang penting dalam pelayanan. Daya tanggap (responsiveness), yaitu kepedulian dan kemauan untuk membantu pelanggan dan memberikan pelayanan yang baik adalah bagian dari pelayanan. Tingkat kepedulian dan ketanggapan ini dilihat dari sejauh mana pihak perusahaan bersedia membantu pelanggan. Kesediaan menerima kritik, saran dan komentar yang bersifat pertanyaan maupun keluhan, adanya sarana komunikasi yang tersedia dan memudahkan pelanggan mengetahui informasi tentang layanan yang disediakan perusahaan, misalnya: internet (websitelon-line service), dan papan informasi. Jaminan (assurance), yaitu pengetahuan dan sikap (sopan, ramah, tanggap, bersahabat) dari pegawai serta kemampuan mereka dalam menanamkan kepercayaan dan keyakinan. Kepedulian (empathy), yaitu tingkat kepedulian dan perhatian perusahaan pada pelanggannya secara individu. Empati pada pelanggan misalnya: tanggap terhadap permasalahan pelanggan berkaitan dengan layanan yang diberikan oleh perusahaan, menyediakan waktu untuk mendengarkan keluhan, memperlakukan pelanggan yang komplain atas layanan dengan baik.

Model implementasi kebijakan publik yang dikembangkan oleh Brian W Hogwood dan Lewis A. Gunn dalam Wahab (2014) mensyaratkan implementasi suatu kebijakan publik dapat dilaksanakan jika: Kondisi eksternal yang dihadapi oleh instansi pelaksana tidak akan menimbulkan gangguan yang serius., untuk pelaksanaan program, tersedia waktu dan sumber-sumber yang cukup memadai, perpaduan sumber-sumber yang diperlukan benar-benar tersedia, kebijakan yang akan diimplementasikan didasari oleh suatu hubungan kausalitas yang andal, hubungan kausalitas bersifat langsung dan hanya sedikit mata rantai penghubungnya, hubungan saling ketergantungan harus kecil, pemahaman yang mendalam dan kesepakatan terhadap tujuan, tugas-tugas diperinci dan ditempatkan dalam urutan yang tepat, komunikasi dan koordinasi yang sempurna, pihak-pihak yang memiliki wewenang kekuasaan dapat menuntut dan mendapatkan kepatuhan yang sempurna.

Teknologi Informasi menurut Australian National Training Atuhority adalah pengembangan aplikasi komputer dan teknologi berbasis komunikasi untuk memproses penyajian, mengelola data dan informasi. Teknologi informasi adalah alat yang digunakan untuk mengolah data, termasuk memproses, mendapatkan, menyusun, menyimpan, memanipulasi data dalam berbagai cara untuk menghasilkan informasi yang berkualitas, yaitu informasi yang relevan, akurat dan tepat waktu, yang digunakan untuk keperluan pribadi, bisnis dan pemerintahan. Dalam pemerintahan dan merupakan informasi yang strategis dalam mengambil keputusan. (Supriyanto 2005).

Menurut Wibawa (1994) manfaat penggunaan teknologi informasi dalam proses administrasi, pengelolaan dan pengurusan negara adalah sebagai berikut pertama, transparansi. Politik dan administrasi (dalam arti sempit) menjadi lebih terbuka, kecurigaan antar aktor berkurang, meskipun kemudian pertengkaran antar aktor juga dapat leluasa ditonton (secara berulang-ulang) melalui televisi. Kedua, partisipasi. Tersampaikannya informasi secara cepat di antara pemerintah dan masyarakat, baik pengusaha atau konsumen ataupun warga biasa. Pers atau media massa dapat lebih leluasa bekerja. Kebebasan berpendapat, bersuara, dan berorganisasi juga lebih terekspresikan. 
Masyarakat mempunyai power yang lebih tinggi, menjadi lebih berdaya. Ketiga, efisiensi. dengan arus informasi yang lancar, maka proses pelayanan masyarakat juga dapat lebih cepat. Proses kerja pemerintah dapat dipersingkat, jenjang birokrasi dapat dipangkas.

Pemanfaatan teknologi informasi dalam pemerintahan masih menemui banyak kendala. Berdasarkan hasil survei Bappenas, terdapat empat kendala penerapan teknologi informasi dalam pemerintahan yaitu belum siapnya departemen atau institusi dalam memanfaatkan teknologi informasi untuk menyelenggarakan kepemerintahan yang baik, Informasi yang dapat diakses oleh publik masih amat terbatas, Infrastruktur teknologi dalam suatu institusi belum baik, SDM dalam menjalankan teknologi informasi belum tersedia dengan baik dilihat dari kualitas ataupun kuantitasnya (Akadun 2009; Jimmy 2008).

\section{Metode Penelitian}

Dalam penelitian ini, peneliti menggunakan metode desktiptif kualitatif karena permasalahan yang kompleks serta membutuhkan pengertian makna secara mendalam, sehingga perlu dilakukan wawancara, observasi maupun dokumentasi secara mendalam agar mampu mendapat data yang valid. Dalam penelitian ini, wawancara dan observasi dilakukan di Polres Gresik. Untuk subjek dalam penelitian ini adalah sesorang yang dinilai mengetahui bagaimana penerapan Go Sigap di Polres Gresik. Berikut merupakan daftar subjek penelitian yang dijadikan narasumber meliputi bagian operasional polres, seksi teknologi dan informasi, keuangan, dan operator Go Sigap.

Sumber data yang digunakan adalah data primer, yang merupakan kata-kata dan tindakan dan data sekunder yang berasal dari sumber tertulis dapat dibagi atas sumber buku dan majalah ilmiah, sumber data arsip, dokumen pribadi, dan dokumen resmi Polres Gresik. Mengenai teknik pengumpulan data yaitu sebagai berikut melalui wawancara atau menghimpun bahan keterangan yang dilakukan dengan tanya jawab secara lisan secara sepihak berhadapan muka, dan dengan arah serta tujuan yang telah ditetapkan (Sudijono 2006). Selain wawancara digunakan pula metode dokumentasi atau mencari data yang berupa catatan, transkrip, buku, surat kabar, majalah, notulen rapat, legger, agenda dan sebagainya. Dalam melakukan analisis data, peneliti menggunakan analisis interaktif yaitu meliputi tahap pengumpulan data, reduksi data, penyajian data dan penarikan kesimpulan.

\section{Hasil dan Pembahasan}

\section{Penerapan aplikasi Go Sigap di wilayah hukum Polres Gresik}

Gresik merupakan salah satu kabupaten yang menjadi penyangga perekonomian Jawa Timur. Perekonomian Kabupaten Gresik ditopang sebagian besar oleh menjamurnya berbagai macam industri. Menurut data Dinas Perindustrian dan Perdagangan Gresik, perkembangan industri di Gresik dari tahun 2002 hingga 2006 mencapai 761 unit dengan nilai investasi Rp1,23 triliun dan mampu menyerap tenaga kerja 30.429. Produk industri Gresik yang dipasarkan ke luar negeri antara tahun 2003 sampai 2007 sebesar 891,29 ton dengan nilai perputaran uang Rp1,423 triliun.

Keberadaan beberapa industri di Gresik menjadikan kota itu sebagai sebuah kota dengan potensi ekonomi yang besar dan mengalami kemajuan yang sangat pesat. Secara ekonomis, kehadiran industri-industri besar di Gresik menjadi sarana penting dalam meningkatkan kesejahteraan penduduk daerah ini. Para pedagang bermunculan di sekitar pabrik, demikian juga dengan jasa pemondokan (kos) bagi para pekerja dan pegawai pabrik menjadi lahan yang cukup menguntungkan. Keterlibatan pabrik untuk ikut serta berperan dalam menjaga kondisi sosial dan berperan aktif dalam usaha mensejahterakan masyarakat sekitar menjadi tujuan dari pemerintah untuk terlibat dalam mengawasi berjalannya industrialisasi di Gresik. Industri-industri di Gresik juga mendirikan beberapa infrastruktur sosial Gresik, seperti pabrik semen yang mendirikan rumah sakit, sekolah, sarana pertokoan, dan sebagainya (Nora 2016). 
Masyarakat Gresik saat ini secara sekilas akan didapat gambaran bahwa sedang terjadi proses industrialisasi. Industri merupakan salah satu variabel pendorong perubahan sosial yang dominan dalam abad-abad terakhir, sehingga kehadiran industri tersebut menemukan apa yang disebut sebagai masyarakat industri yang berbeda dengan masyarakat agraris (Kuntowijoyo 1991).

Perubahan sosial masyarakat Gresik akibat industrialisasi yang menjadikan masyarakat menjadi masyarakat modern dengan pikiran terbuka berpengaruh pula pada bagaimana orientasi pemikiran mereka terhadap perubahan. Dalam masyarakat pra-modern (tradisional), perubahan berjalan lambat. Makin maju masyarakat makin cepat perubahannya. Masyarakat modern adalah masyarakat yang senantiasa berubah cepat, bahkan perubahan itu melembaga. Perubahan ini merupakan ciri yang senantiasa dihadapi masyarakat modern, dan perubahan itu didorong dan dipercepat oleh perkembangan ilmu pengetahuan dan teknologi, yang roda percepatannya bergerak dengan intensitas yang makin tinggi.

Terkait penelitian mengenai adanya inovasi Go Sigap yang mengubah budaya konvensional dalam hal pelayanan mejadi berbasis teknologi informasi, berdasarkan analisis penulis akan bisa diterima dengan mudah oleh masyarakat Gresik karena tipikal heterogenistas masyarakat Gresik saat ini memiliki sikap hidup yang dapat menerima hal-hal baru dan terbuka untuk perubahan. Dari segi keunggulan fitur yang terdapat dalam aplikasi Go Sigap ini adalah registrasi online, informasi dini, laporan masyarakat, alamat penting, pelayanan online, panic button. Untuk proses pembentukan Go Sigap sebagai inovasi kebijakan berbasis teknologi dan informasi, maka dalam penelitian ini proses tahapan pembentukan kebijakan baru terkait implementasi inovasi teknologi dijelaskan berdasarkan teori "inovationdecision prosess" yang dinyatakan oleh Rogers menggunakan lima langkah atau tahapan berikut ini: (1) pengetahuan (knowledge), (2) bujukan (persuasion), (3) keputusan (decision), (4) pelaksanaan (implementation), dan (5) konfirmasi (confirmation). langkah-langkah tersebut di atas dijelaskan secara lebih detail sebagai berikut:

Tahap pengetahuan (knowledge stage), adalah tahap ketika penggagas kebijakan yakni Kapolres Gresik Adex Yudiswan menelaah Rencana Aksi 100 hari penjabaran Program Prioritas Promoter tentang modenisasi pelayanan umum dengan mewujudkannya melalui inovasi berbasis teknologi informasi dan komunikasi. Setelah proses penelaahan rencana kebijakan tersebut, kemudian kapolres berusaha mencari informasi, berkomunikasi dengan berbagai pihak dan kemudian mendapatkan pengetahuan dan pemahaman tentang inovasi pelayanan publik berbasis teknologi informasi dan komunikasi.

Tahap bujukan (persuasion stage), pada penelitian ini, inovasi aplikasi Go Sigap dilatarbelakangi oleh adanya perubahan era digital dalam pelayanan kepolisian adalah adanya aplikasi Go Sigap. Aplikasi Go Sigap merupakan aplikasi dengan sistem operasi berbasis android yang dirancang dan dibangun oleh Polres Gresik pada September tahun 2016 yang lalu. Aplikasi Go Sigap merupakan bagian dari sistem informasi manajemen layanan elektronik kepolisian. Inovasi aplikasi Go Sigap saat proses penyusunan kebijakan diprediksikan dapat diterima oleh sebagian besar masyarakat dan aparat kepolisian oleh karena mudah untuk digunakan dan praktis serta dapat membantu mereka dalam menanggapi tindakan kriminalitas yang terjadi sehingga "penawaran" kemudahaan operasional program serta kemudahan pelayanan publik merupakan kunci persuasif yang baik pada masyarakat untuk menerima program ini.

Tahap Keputusan (decision stage), munculnya inovasi Go Sigap merupakan dorongan secara politis dari pusat yaitu Kepolisian Negara Republik Indonesia melalui Program Promoter Kapolri. Adanya Go Sigap merupakan dari program peningkatan pelayanan publik yang lebih mudah bagi masyarakat dan berbasis TI. Hal tersebut yang mendorong Kapolres untuk memutuskan membuat inovasi pelayanan berbasis aplikasi android yang terintegrasi dan terhubung dengan seluruh Polres Gresik yaitu Go Sigap. Keyakinan pembuatan keputusan untuk meluncurkan program ini juga karena adanya dukungan dari pemerintah pusat, pemerintah daerah dan lembaga negara lainnya turut mendukung adanya inovasi Go Sigap baik secara moril, materiil maupun mebantu dalam hal sosialisasi kepada masyarakat. Dukungan secara moril diberikan oleh Menteri Pendayagunaan Aparatur Negara dan 
Reformasi Birokrasi yang hadir pada saat launching inovasi Go Sigap. Dukungan dalam membantu sosialisasi Go Sigap kepada masyarakat dilakukan oleh humas instansi pemerintah lainnya dengan saling membantu menginformasikan melalui sosial media.

Tahap pelaksanaan (implementation stage), pada tahap penerapan aplikasi ini, aparat kepolisian dilapangan merasa perlu untuk menggunakannya dan dapat menemukan manfaatnya, terutama untuk tetap siaga dalam bertugas. Hasil obeservasi penulis menjelaskan bahwa implementasi inovasi Go Sigap tidak hanya memiliki keunggulan relatif, kompabillitas, triabillity dan observabillity tetapi juga kompleksitas. Faktor pendorong inovasi Go Sigap adalah dorongan politik dan peningkatan efisiensi dan tekanan untuk meningkatkan layanan.

Tahap konfirmasi (confirmation stage), dari hasil penelitian yang dilakukan, peneliti menyimpulkan bahwa anggota kepolisian setempat mengadopsi atau menerima adanya aplikasi Go Sigap. Tentunya anggota kepolisian setempat sudah mempertimbangkan setelah mengalami tahapan-tahapan seperti yang telah dijelaskan di atas, barulah mereka memutuskan untuk menerima aplikasi tersebut.

Selain dari internal kepolisian, masyarakat juga menerima kehadiran dari program ini. Untuk total download aplikasi di playstore mencapai angka lebih dari 10 ribu download dan untuk masyarakat yang melakukan registrasi tercatat mencapai angka 5650. Selain itu banyaknya penghargan terhadap program ini menandakan diterimanya program ini di masyarakat. Beberapa penghargaan Go Sigap ini antara lain apresiasi dari Menteri Pendayagunaan Aparatur Negara dan Reformasi Birokrasi yang diberikan dalam Gelar Inovasi Pelayanan Publik di Polda Jatim. Dalam acara tersebut Go Sigap diajukan oleh Polres Gresik sebagai bentuk inovasi pengayoman, perlindungan dan pelayanan bagi masyarakat.

Kemudian, penghargaan dari Menteri Pendayagunaan Aparatur Negara dan Reformasi Birokrasi untuk inovasi aplikasi Go Sigap sebagai inovator dalam forum Nasional Replikasi Inovasi Pelayanan Publik dalam acara Pameran dan Workshop yang diselenggarakan di Bandung tanggal 26-27 Oktober 2016 dan penghargaan dari Kapolri terhadap Go Sigap sebagai Program PROMOTER terbaik. Di samping itu, penghargaan dari Kapolri terhadap Polres Gresik atas prestasinya berupa kinerja dengan Indeks Tata Kelola Polri (ITK) mencapai Nilai 5,764.

Jika dilihat dari keunggulannya, aplikasi ini jelas berfungsi sebagai penunjang efisensi administrasi kepolisian. Fitur pemberitahuan SP2HP melalui aplikasi Go Sigap merupakan bentuk transparansi Polri dengan menggunakan Sistem Informasi Manajemen khususnya Sistem Informasi Penyidikan sebagaimana diatur dalam Peraturan Kepala Kepolisian Negara Republik Indonesia Nomor 21 Tahun 2011 tentang Sistem Informasi Penyidikan Tata Cara Penyampaian Informasi Penyidikan, Pasal 10 yang mengatur mengenai penyampaian informasi penyidikan dilakukan melalui surat, website, telepon atau SMS gateway, dan media cetak dan elektronik. Efisiensi pada mekanisme administratif juga didapatkan pada masyarakat yang melakukan pembuatan atau perpanjangan SIM. Dengan menggunakan aplikasi Go Sigap maka akan tercipta efisiensi waktu pemohon pembuat atau perpanjangan SIM karena hanya dengan memasukkan booking code atau scan QR code yang untuk berikutnya formulir pengajuan SIM tersebut akan tercetak secara otomatis.

Dalam lingkup internal Go Sigap secara administratif memberikan solusi pengadministrasian secara elektronik. Dalam hal laporan polisi melalui Go Sigap, maka petugas polisi piket bagian reserse krimininal dan SPKT dengan mudah mendapatkan informasi pelapor tanpa harus mengetik ulang karena setelah scan QR code atau memasukkan booking code, data yang diisi oleh pengguna "Go Sigap Masyarakat" akan otomatis terisi sesuai dengan form laporan polisi. Petugas piket hanya perlu pengecekan ulang dan merevisi apabila ada kesalahan kemudian dicetak, dan data tersebut otomatis tersimpan pada bank data Go Sigap. Dengan administrasi elektronik ini pula pimpinan yakni kapolres pun dapat dengan mudah memantau jumlah laporan yang masuk menggunakan menu laporan dalam aplikasi ini jika login sebagai "admin". Menu yang bisa ditampilkan berisi laporan data periodik dengan memasukkan tanggal awal dan tanggal akhir pada form periode serta dapat melihat jumlah laporan yang masuk melalui aplikasi go Sigap. 
Keunggulan lain adalah Aplikasi Go Sigap ini berfungsi sebagai program yang mengutamakan kualitas pelayanan. Dalam menilai kualitas layanan dari implementasi Aplikasi Go Sigap, penulis mendasarkan pada indikator yang dikemukakan dalam Zeithmal dan Berry yang memberikan batasan pada lima dimensi pokok yang berkaitan dengan kualitas layanan. Kelima dimensi kualitas layanan tersebut antara lain penampilan, kehandalan, daya tanggap, jaminan (Tjiptono 2003) Analisis mengenai kelima dimensi tersebut dipaparkan sebagai berikut :

Penampilan (tangible), penampilan fisik terdiri dari beberapa elemen yang jika dikaitkan dengan dukungan terhadap aplikasi Go Sigap adalah sebagai berikut:

Beroperasi secara penuh 7 x 24 jam, perencanaan terhadap kapasitas secara fisik optimal, memiliki cukup ruangan untuk ekspansi, memiliki sumber power yang terpisah, memiliki back-up generator tersendiri, UPS memiliki kapasitas yang cukup, dan sistem pendingin yang beroperasi secara penuh, menggunakan sistem pemadam kebakaran sendiri dan automatis, bahan dinding ruangan memiliki ketahanan terhadap api, rak server tertutup dan terkunci, terdapat petunjuk evakuasi ketika kondisi darurat, kamera CCTV terletak di dalam maupun luar data center dan sistem perkabelan yang termanage dan memiliki label.

Kehandalan (reliability) yaitu, kemampuan dalam memenuhi janji, tepat waktu, konsisten dan kecepatan pelayanan merupakan hal yang penting dalam pelayanan. Berdasarkan wawancara dengan operator Go Sigap, mengenai kehandalan petugas dalam maka didapatkan fakta bahwa Sistem Go Sigap seperti gojek. Jadi masyarakat yang meminta bantuan akan didatangi polisi terdekat datang. Fungsi operator disini adalah melakukan pengawasan. Jika polisi terdekat tidak mendatangi TKP maka disinilah operator bergerak untuk menghubungi Polisi yang terdekat dengan TKP. Jika terjadi kebakaran membutuhkan kehadiran back up dari mitra Polri (PMK ambulance) maka polisi terdekat TKP yang melakukannya.

Daya tanggap (responsiveness) yaitu, kepedulian dan kemauan untuk membantu masyarakat dan memberikan pelayanan yang baik adalah bagian dari pelayanan. Tingkat kepedulian dan ketanggapan ini dilihat dari sejauh mana pihak kepolisian bersedia membantu masyarakat. Pada indikator ini jika dikaitkan dengan daya tanggap petugas pada layanan aplikasi Go Sigap, maka fitur panic button menjembatani mengenai hal ini. Pada fitur ini jika masyarakat menekan "panic button" maka dalam hitungan menit Polisi bisa tiba di TKP. Untuk menghindari berpindahnya lokasi TKP maka tiap 1 menit sekali HP pengguna fitur ini akan mengirim sinyal lokasi (lokasi terkini) pada operator dan Kepolisian yang ditugaskan menuju lokasi pelapor.

Jaminan (assurance), Zeithaml menyatakan bahwa kualitas pelayanan pada indikator assurance dapat diukur dari 3 dimensi, yaitu : Jaminan tepat waktu pelayanan, untuk menjamin operasionalisasi tepat waktu pelayanan Go Sigap pada fitur Panic Button, maka dilibatkanlah beberapa piket fungsi di Polres Gresik dan Polsek jajaran setiap hari 1 x 24 jam. Jaminan kepastian dalam pelayanan, mengenai kepastian pelayanan ini diketahui dari wawancara informan yang menyatakan bahwa Pelayanan public sebelumnya dilakukan dengan datang langsung mengisi berkas-berkas yang bersangkutan dengan kasus kemudian menunggu konfirmasi baru ditindak lanjuti dan proses ini memburtuhkan waktu yang lama sehingga adanya aplikasi Go Sigap ini lebih efisien oleh karena tidak memerlukan banyak waktu atau lebih cepat. Pegawai memiliki pengetahuan yang luas tentang pelayanan, sebagai operator dituntut untuk menguasai semua layanan di kepolisian. Sehingga jika ada masyarakat yang menanyakan mengenai suatu permasalahan akan dapat dijawab dengan detail.

Kepedulian (empathy), tingkat kepedulian dan perhatian organisasi pada pelanggannya secara individu. Empati pada pelanggan misalnya : tanggap terhadap permasalahan pelanggan berkaitan dengan layanan yang diberikan oleh perusahaan, menyediakan waktu untuk mendengarkan keluhan, memperlakukan pelanggan yang komplain atas layanan dengan baik. Hal inilah yang menjadi landasan dari pelayanan Go Sigap. Fitur Chat room dengan operator bagi pengguna layanan Go Sigap adalah berguna untuk membicarakan lebih intens apa yang menjadi keluhan masyarakat. 


\section{Kendala penerapan aplikasi Go Sigap Di wilayah hukum Polres Gresik}

\section{Anggaran jangka panjang serta maintenance aplikasi Go Sigap}

Salah satu faktor yang menjadi penghambat sebuah inovasi adalah anggaran jangka pendek. Jika suatu instansi dalam mengelola inovasi masih mengandalkan anggaran jangka pendek dan tidak memilki perencanaan yang baik berkaitan dengan anggaran jangka pendek maka bisa menghambat inovasi. Go Sigap saat ini belum memilki pos anggaran tersendiri sehingga masih harus berbagi dengan pos anggaran lain dan mendapat bantuan dari dana hibah PT Jaya Shakti Barutama. Mengenai input anggaran operasional terkait anggaran Perencanaan dan Pengembangan Aplikasi Go Sigap yang tidak dimasukkan oleh Polda Jatim pada DIPA (Daftar Isian Pelaksanaan Anggaran) tahun 2017 dan tahun 2018 menyebabkan operasional khususnya pada maintenance aplikasi menjadi terkendala. Saat ini memang ada solusi jangka pendek yakni didapatkannya dana hibah dari PT Jaya Shakti Barutama tetapi untuk menjadikan program ini secara kontinyu mendapatkan plotting bantuan anggaran, maka menjadikan Apliksi Go Sigap sebagai Program Nasional harus dilakukan.

\section{Kendala masalah teknologi informasi dan komunikasi}

Untuk masalah keamanan aplikasi berdasarkan obeservasi penulis, saat ini komputer baik untuk operasional, server sebagai penyimpanan data telah memiliki sistem anti virus, tetapi anti virus yang digunakan masih konvensional atau manajemen anti virus dilakukan dilokal PC atau server saja. Potensi adanya anti virus yang tidak up to date sehingga berpotensi terserang virus sangatlah besar. Anti virus yang digunakan pun tidak terstandar dari Pusat sehingga penanganan jika terjadi serangan virus pun dilakukan tanpa SOP dari pusat tetapi hanya berdasarkan pengalaman anggota atau jika ada kesulitan penanganan maka akan memanggil pihak ketiga sebagai pembuat aplikasi Go Sigap untuk menyelesaikan permasalahan serangan virus. Sudah seharusnya untuk mengatasi hal ini Divisi TIK Polri melakukan standardisasi penggunaan anti virus sehingga bisa mempersempit penggunaan pihak ketiga untuk melakukan maintenance terhadap sistem komputer Polri yang berisi berbagai informasi penting. Untuk mengatasi kendala tersebut seharusnya Polri seharusnya mengimplementasikan sistem teknologi keamanan jaringan dari Mabes hingga ke Satuan Kewilayahan. Sehinga sistem keamanan jaringan akan memenuhi standar keamanan TIK yang telah dibuat dan hanya memiliki 1 gateway ke internet.

\section{Kendala penguasaan SDM terhadap teknologi dan informasi}

Terkait dengan kompetensi SDM di Polres Gresik, yang salah satu bagian yang bertanggung jawab terhadap Teknologi Informasi Go Sigap Polres Gresik adalah Seksi Teknologi Informasi Polri yang selanjutnya disingkat Sitipol. Kendala yang ada pada Sitipol Polres Gresik berdasarkan observasi penulis adalah :Tidak ada SDM di Polres Gresik yang mempunyai kompetensi yang cukup dibidang Maintenance aplikasi Go Sigap. Hal ini berpotensi terjadinya pemborosan anggaran serta asset SDM bila kualifikasi SDM tentang maintenance aplikasi tidak di-upgrade untuk penguasaan maintenance program-program aplikasi berbasis android; Sitipol Polres Gresik belum memiliki job description dan job spesification yang jelas mengenai penanganan dan pengembangan Go Sigap.

Maka dari itu perlu dilakukan job analysis yaitu perumusan job description dan job specification job description dan job spesification untuk setiap jabatan SDM Sitipol yang belum memiliki sertifikasi TIK. Seharusnya perlu disusun terlebih dahulu daftar sertifikasi TIK yang harus dimiliki SDM Sitipol; Belum memiliki perencanaan pelatihan dan kurikulum pelatihan TI. Sehingga perlu dilakukan Perlu disusun perencanaan pelatihan dan kurikulum pelatihan termasuk e- learning. Seharusnya untuk meningkatkan kompetensi TI diperlukan berbagai pelatihan antara lain: Pelatihan Pemrograman, Pelatihan Jaringan TIK, Pelatihan Keamanan TIK, Pelatihan Radio Komunikasi, serta Pelatihan Manajemen TIK. Mengenai kurikulum e-learning (e-lab untuk pelatihan SDM Sitipol) yang memungkinkan dengan $e$-learning adalah terlebih dahulu melakukan pengumpulan data dan informasi mengenai kurikulum e-learning yang ada di lingkungan POLRI, kemudian menyusun modul elearning (e-lab), melakukan analisis kesiapan teknologi dalam implementasi e-learning (e-lab), Uji 
coba modul e-learning (e-lab) juga perlu dilakukan untuk kemudian melakukan koordinasi dengan Lemdikpol mengenai modul $e$-learning untuk memperoleh masukan dan menyusun pedoman final $e$ learning (e-lab).

\section{Tidak adanya sertifikasi terhadap aplikasi Go Sigap sebagai bentuk jaminan perlindungan data pribadi masyarakat pengguna aplikasi}

Aplikasi Go Sigap adalah suatu kegiatan penyelenggaraan sistem elektronik karena terdapat perangkat keras berupa komputer sebagai pengoperasi perangkat lunak yakni aplikasi atau software Go Sigap yang dikendalikan oleh tenaga ahli untuk mengelola informasi elektronik berupa berbagai macam informasi, pendaftaran online serta pengumpulan informasi masyarakat dari mekanisme login atau registrasi pengguna. (Pasal 4 PP PSTE). Jadi Sebagai penyelenggara negara apapun produk layanan Kepolisian terkait Penyelenggaraan Sistem dan Transaksi Elektronik wajib untuk didaftarkan termasuk sistem elektronik Go Sigap. Polres Gresik seharusnya mendaftarkan aplikasi tersebut sebagaimana diatur dalam Pasal 5 ayat 1 PP PSTE yang menyebutkan bahwa Penyelenggara Sistem Elektronik untuk pelayanan publik wajib melakukan pendaftaran.

Pendaftaran aplikasi Go Sigap tersebut adalah sebagai bentuk pertanggungjawaban jaminan keamanan data masyarakat. Sebagaimana diketahui Go Sigap juga mengumpulkan data pribadi masyarakat sehingga jaminan keamanan sistem harus tersertifikasi pula. Tanpa dilakukan pendaftaran maka sertifikasi kelaikan sistem elektronik guna menjamin keamanan data masyarakat juga tidak bisa dilakukan.

\section{Cepatnya pergantian kepemimpinan dalam kepolisian}

Tidak dapat lamanya seorang pimpinan Polri di daerah baik provinsi maupun kabupaten/kota atau kecamatan, karena adanya kebijakan Tour of duty atau mutasi anggota berdasarkan penugasan jabatan. Hal mendasar dengan adanya pergantian kepemimpinan adalah adanya perubahan organisasi. Setiap pergantian kepemimpinan di jajaran Polres Gresik, Kapolres baru pasti akan membawa perubahanperubahan baru dalam institusi maupun di luar institusi yang berpengaruh langsung terhadap masyarakat.

Dalam teori kepemimpinan, bagi pimpinan yang memasuki organisasi baru dan akan melakukan perubahan di dalamnya sementara dalam organisasi tersebut terdapat program kerja pimpinan lama yang telah berjalan dengan bagus dan mendapat apresiasi kinerjanya, maka yang harus dilakukan oleh pimpinan baru adalah dengan melakukan evaluasi dan pengembangan terhadap kebijakan lama. (Winarno 2008).

Artinya kebijakan lama akan bisa tidak diteruskan atau kurang berjalan maksimal jika terjadi perubahan kepemimpinan. Maka seharinya saat pergantian kepemimpinan, kapolres baru harus melakukan evaluasi terhadap program Go Sigap, para Pimpinan atau Kapolres dalam masa transisi ini melakukan analisis dengan model integratif (Suharto, 2012). Dengan melakukan evaluasi kebijakan model integratif tersebut akan memberikan gambaran bagi kapolres baru mengenai Go Sigap terkait empat hal sebagaimana dalam teori Riant Nugroho (2003) yakni eksplanasi.

Melalui evaluasi dapat dipotret realitas pelaksanaan program dan dapat dibuat suatu generalisasi tentang pola-pola hubungan antar berbagai dimensi realitas yang diamatinya; Kepatuhan. Melalui evaluasi ini dapat diketahui apakah tindakan yang dilakukan anggota Polres Gresik, Mitra Polisi sudah sesuai dengan standar dan prosedur yang ditetapkan atau tidak; Audit. Dengan mengaudit pelaksanaan Go Sigap maka dapat diketahui mengenai total anggaran saat rancang bangun serta angaran untuk melakukan maintenance program. Dari sini dapat diketahui pula mengenai strategi yang efektif untuk mengatasi berbagai permasalah dalam hal perencanaan dan pengeluaran keuangan dalam pelaksanaan Go Sigap; Akunting. Dengan evaluasi dapat diketahui apa akibat sosial ekonomi dari kebijakan Go Sigap tersebut terhadap masyarakat dan kemudian merumuskan arah kebijakan dinamis yang bisa lebih meningkatkan arah sosial ekonomi masyarakat dalam pelaksanaan Go Sigap. 


\section{Potensi terjadinya tumpang tindih kebijakan}

Pada saat Aplilkasi Go Sigap sudah berjalan, pada tanggal 18 Desember 2016 Divisi TIK Mabes Polri membuat aplikasi yang hampir sama dan bersifat nasional yang nantinya akan diterapkan ke seluruh Indonesia. Aplikasi ini disebut dengan aplikasi "PolisiKu". Aplikasi ini bisa ditanam / di-install pada smartphone Android atau iOS (Apple Phone) sehingga masyarakat dengan mudah dapat mendownload dari PlayStore dan AppleStore. Fungsi dari program ini adalah agar masyarakat merasa nyaman dan mudah berinteraksi dengan polisi, di manapun sedang berada. Program ini memiliki 6 (enam) menu utama pada program "PolisiKu" yakni mencari Layanan Polisi Terdekat; mencari Layanan Polisi di Kota Lain; Pengaduan Masyarakat; Info Humas mencari bantuan; Halo Polisiku (Keluhan dan Apresiasi kepada Polisi); Layanan Lain ( SKCK,SAMSAT,SIM ONLINE). Terkait dengan adanya aplikasi Polisiku dan Aplikasi Go Sigap yang secara bersama-sama eksis sebagai aplikasi penyedia layanan berbasis teknologi informasi dari instansi Polri, maka hal ini pada dasarnya adalah suatu kebijakan yang ada dalam Rencana Aksi 100 hari penjabaran Program Prioritas Promoter.

Tidak dikomunikasinnya program Polisiku dengan masing-masing KOD atau satuan kewilayahan serta sikap keterburu-buruan dalam pengambilan kebijakan juga membuat terjadinya tumpang tindih kebijakan yang saat ini ada yakni Go Sigap. Pada kasus-kasus implementasi kebijakan demikian diperlukan petunjuk pelaksanaan dan SOP yang jelas dan terperinci, selain pengawasan yang ketat agar implementasi kebijakan berjalan sesuai dengan struktur yang telah ditentukan. Dengan adanya tumpang tindih kebijakan pelayanan publik dengan dipakainya aplikasi yang sama antara Mabes Polri (aplikasi Polisiku) dan Polres Gresik (Aplikasi Go Sigap) maka akan bisa membuat masyarakat menjadi bingung mengunakan aplikasi mana yang ia harus gunakan untuk mendapatkan pelayanan publik dari Polri di wilayahnya. Selain itu sosialisasi yang dilakukan masing-masing KOD melalui media sosial, Bhabinkamtibmas atau melalui berbagai forum kemasyarakatan pun akan menjadi tidak terfokus lagi. Yang mana sebelumnya misalnya mensosialisasikan Go Sigap, kemudian harus mensosialisasikan aplikasi yang sama yakni Polisiku, sementara aplikasi Go Sigap masih berjalan sampai saat ini.

\section{Simpulan}

Masyarakat Kabupaten Gresik diyakini dapat menerima adanya aplikasi Go Sigap, dikarenakan masyarakat Gresik saat ini terjadi perubahan sosial masyarakat Gresik akibat industrialisasi yang menjadikan masyarakat menjadi masyarakat modern dengan pikiran terbuka. Pembentukan go sigap sebagai inovasi kebijakan berbasis teknologi dan informasi telah sesuai dengan tahapan pada pembentukan kebijakan berbasis inovasi teknologi informasi yakni melalui tahapan yaitu: (1) pengetahuan (knowledge); (2) bujukan (persuasion); (3) keputusan (decision); (4) pelaksanaan (implementation); dan (5) konfirmasi (confirmation). Keunggulan Aplikasi Go Sigap ini antara lain adalah yang pertama dari fitur menunya menjadikan aplikasi ini berguna sebagai penyedia informasi dini mengenai suatu kondisi tertentu dalam masyarakat berpotensi bagi munculnya gejolak sosial atau tidak; adanya laporan polisi online; sebagai sumber informasi berbagai alamat penting; pelayanan online untuk pengurusan SIM dan SKCK; serta digunakan sebagai panic button yang menandakan ada bahaya yang sedang terjadi pada pengguna aplikasi. Kedua, keunggulan aplikasi ini adalah sebagai penunjang efisiensi administrasi kepolisian. Ketiga, terjaminnya kualitas pelayanan dari Go Sigap yang dibuktikan dengan telah terpenuhinya 5 dimensi kualitas pelayanan mulai dari aspek penampilan (tangible), kehandalan (reliability), daya tanggap (responsiveness), jaminan (assurance), serta kepedulian (empathy).

Mengenai kendala penerapan aplikasi Go Sigap di wilayah hukum Polres Gresik antara lain kendala anggaran jangka panjang dan maintenance aplikasi go sigap. Kendala kedua adalah masalah teknologi informasi dan komunikasi yakni dengan belum optimalnya sistem manajemen dan jaringan komunikasi data wireless di seluruh satuan kewilayahan termasuk di Polres Gresik, keamanan aplikasi sistem anti virus yang digunakan masih konvensional atau manajemen anti virus hanya dilakukan dilokal PC atau server saja serta tidak terstandar dari pusat. Kendala ketiga adalah kendala penguasaan SDM Polres Gresik terhadap teknologi dan informasi misalnya tidak ada SDM di Polres Gresik yang 
mempunyai kompetensi yang cukup dibidang Maintenance aplikasi Go Sigap, Sitipol Polres Gresik belum memiliki job description dan job spesification yang jelas mengenai penanganan dan pengembangan Go Sigap, SDM Sitipol belum memiliki sertifikasi TIK serta belum adanya perencanaan pelatihan dan kurikulum pelatihan TI. Kendala keempat adalah tidak adanya sertifikasi terhadap aplikasi Go Sigap. Kendala kelima, adalah cepatnya pergantian kepemimpinan dalam Polres gresik yang mengakibatkan tidak optimalnya kinerja Go Sigap sebagai aplikasi layanan publik. Kendala terakhir yakni adanya potensi terjadinya tumpang tindak kebijakan pada aplikasi yang sama yakni aplikasi Polisi yang dikeluarkan oleh Div TIK Mabes Polri.

\section{Daftar Pustaka}

Akadun (2009) Teknologi Informasi Administrasi. Bandung: Alfabeta.

Fandy T \& Anastasia D (2003) Total Quality Management. Yogyakarta: Yogyakarta Press.

Hardiyansyah (2011) Kualitas Pelayanan Publik Konsep, Dimensi, Indilator dan Implementasinya. Yogyakarta: Gaya Media.

Ibrahim (1988) Inovasi Pendidikan, Proyek Pengembangan LPTK Depdikbud. Jakarta: Dikti.

Jimmy LG \& Chr (2008) Sistem Informasi Manajemen Pemahaman dan Aplikasi. Jakarta: PT. Grasindo.

Kuntowijoyo (1991) Paradigma Islam: Interpretasi untuk Aksi. Bandung: Mizan.

Moleong LJ (2010) Metodologi Penelitian Kualitatif Edisi Revisi. Bandung: PT Remaja Rosdakarya.

Nina R (2013) Manajemen Pelayanan Prima. Yogyakarta: Graha Ilmu.

Nora F (2016) Identitas Masyarakat Kabupaten Gresik Pasca-Industrialisasi (Studi atas Perubahan Sosial di Kota Santri). Yogyakarta: Universitas Islam Negeri Sunan Kalijaga.

Ratminto \& Atik (2013) Manajemen Pelayanan. Yogyakarta: Pusaka Pelajar.

Sahya A (2014) Kebijakan Publik. Bandung: Pustaka Setia.

Sudijono A (2006) Pengantar Evaluasi Pendidikan. Jakarta: PT Raja Grafindo Persada.

Sugiono (2011) Metode Penelitian Kuantitatif, Kualitatif, dan R \& D. Bandung: Alfabeta

Suprianto A (2005) Pengantar Teknologi Informasi. Jakarta: Salemba Infotek.

Wahab SA (2014) Analisis Kebijakan Dari Formulasi ke Penyusunan Model-Model Implementasi Kebijakan Publik. Jakarta: Bumi Aksara.

Wibawa S (1994) Evaluasi Kebijakan Publik. Jakarta: Raja Grafindo Persada. 